\title{
Use of Radial Basis Function Neural Network in Estimating Wood Composite Materials According to Mechanical and Physical Properties
}

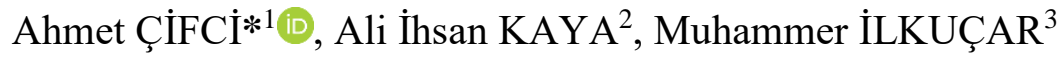 \\ ${ }^{1}$ Department of Electrical-Electronics Engineering, Faculty of Engineering and Architecture, Mehmet Akif \\ Ersoy University, Burdur, Turkey \\ ${ }^{2}$ Department of Design, Vocational School of Technical Sciences, Mehmet Akif Ersoy University, Burdur, \\ Turkey \\ ${ }^{3}$ Department of Management Information Systems, Faculty of Management, Muğla Sttkı Koçman University, \\ Muğla, Turkey
}

Geliş / Received: 30/05/2018, Kabul / Accepted: 23/01/2019

\begin{abstract}
Knowing the mechanical and physical properties of a material is the most important criteria for engineers and designers interested in determining the intended use of the material. The prediction of wood composite materials based on their mechanical and physical properties plays an important role in their future application. In this study, radial basis function network approach was employed for prediction according to mechanical and physical properties of wood composite materials such as particleboard, fiberboard, oriented strand board and plywood, which have widespread use in the furniture industry and construction sector. Four physical and mechanical properties were used as the board density, bending strength, bending elastic modulus and tensile strength in the prediction of the wood composite materials. This study will assist wood composite users in the selection of wood composite materials that will provide the mechanical and physical properties determined in advance for any construction. Moreover, the present study will fill this gap in literature.
\end{abstract}

Keywords: Physico-mechanical properties, Plywood, Fiberboard, Radial basis function neural network, Particleboard, Oriented strand board

\section{Ahşap Kompozit Malzemelerin Mekanik ve Fiziksel Özelliklerine göre Tahmininde Radyal Temelli Fonksiyon Sinir A ğının Kullanımı}

\section{$\ddot{O} \mathbf{z}$}

Mühendisler ve tasarımcılar açısından bir malzemenin mekanik ve fiziksel özelliklerinin bilinmesi malzemenin kullanım amacının belirlenmesinde en önemli kriterlerdendir. Ahşap kompozit malzemelerin mekanik ve fiziksel özelliklere göre tahmini, gelecekteki ahşap kompozit malzeme uygulamalarında önemli bir rol oynayacaktır. Bu çalışmada mobilya endüstrisinde ve inşaat sektöründe yaygın kullanıma sahip olan yonga levha, lif levha, yönlendirilmiş yonga levha ve kontrplak gibi ahşap kompozit malzemelerin mekanik özelliklerine göre tahmin işlemi radyal temelli fonksiyon ağı ile gerçekleştirilmiştir. Ahşap kompozit malzemelerin tahmininde levha yoğunluğu, eğilme direnci, eğilme elastikiyet direnci ve çekme direnci olarak dört fiziksel ve mekanik özellik kullanılmıştır. Bu çalışma, ahşap kompozit malzeme kullanıcılarının herhangi bir konstrüksiyon için önceden belirledikleri mekanik ve fiziksel özellikleri sağlayacak ahşap kompozit malzemenin seçiminde yardımcı olacaktır. Ayrıca, bu çalışma literatürdeki bu boşluğu dolduracaktır.

Anahtar Kelimeler: Fiziko-mekanik özellikler, Kontrplak, Lif levha, Radyal temelli fonksiyon sinir ağı, Yonga levha, Yönlendirilmiş yonga levha

\section{Introduction}

Over time, increasing global forest loss and rising wood prices have led to the development of wood composite materials, parallel to the development of the chemical and glue industry. The composite term is 
being used to describe any wood material adhesive-bonded together. (Cai and Ross, 2010). These materials have begun to be widely used as engineering design board products that meet consumer demands. Because they eliminate defects of solid wood materials and they are more homogeneous and durable. Thus, wood-based composite materials that are alternative to wood materials have been developed and a wide variety of wood materials have been produced according to the intended use with engineering design. Wood composites are more economical and more useful in many areas than natural wood materials because of the lack of growth defects such as twisted fibers, knots, decay.

A wide variety of engineering properties are used to characterize the performance of woodbased composites. The knowledge of the mechanical properties of these products is critical to their proper use. The mechanical properties of wood composites depend on several factors such as wood species, forest management regimes, the type of adhesive used to bind the wood elements together, geometry of the wood elements and density of the final product. Mechanical properties are typically used most commonly for evaluating wood-based composites for structural and non-structural applications (Cai and Ross, 2010).

There are a growing number of papers in the field of wood science employing artificial neural network (ANN), such as predicting physical and mechanical properties in wood and wood composites (Fernandez et al., 2008; Fernandez et al., 2012; Melo and Miguel, 2016; Ilkucar et al., 2018; Miguel et al., 2018), calculating wood thermal conductivity (Avradimis and Iliadis, 2005; Xu et al., 2007), classifying wood defects (Marcano-Cedeño et al., 2009; Shahnorbanun et al., 2010; Qayyum et al., 2016), optimizing of bonding strength of the various wood products (Cook and Chiu,
1997; Tiryaki et al., 2014) and analysing of moisture in wood (Zhang et al., 2006; Esteban et al., 2010; Özşahin, 2012).

The aim of the paper is to predict wood composite materials such as particleboard, fiberboard, oriented strand board and plywood by using radial basis function (RBF) neural network. Particleboard, fiberboard, oriented strand board and plywood used in this study are shown in Fig. 1. Four physical and mechanical properties such as the board density, bending strength, bending elastic modulus and tensile strength were used in the prediction of the wood composite materials.

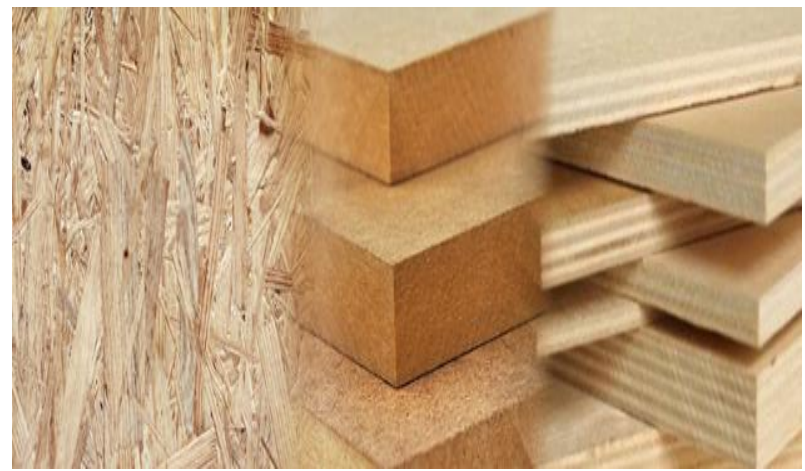

Fig. 1. Wood Composite Materials.

The remainder of this paper is organized in the following way. The next section outlines the main idea of the RBF neural network. Section 3 presents the prediction of wood composite materials. Finally, conclusions are drawn in Section 4.

\section{Radial Basis Function (RBF) Neural Network}

There are many types of ANN architectures, such as Multi-Layer Perceptron (MLP), Long Short-Term Memory (LSTM), Recursive Neural Network (RNN), Convolutional Neural Network (CNN), Self-Organizing Map (SOM) Network and Radial Basis Function Neural Network (Tchircoff, 2018). Different types of network architectures are preferred for solving different problems in the literature. Networks with different architectures can be used as alternatives to each other to solve the 
same problems. Depending on the resources (RAM, processor etc.) used and the calculation method, one can be preferred to the other. MLP and RBF neural networks are alternatives to each other in solving problems such as classification and prediction. The RBF network comes to the forefront in solving problems such as classification and prediction, with fewer resources and ease of calculation. Compared with the other ANN, the RBF neural network has a simple structure and the advantage of faster learning speed. The RBF neural networks as shown in Fig. 2 consist of three layers, the first layer considered as input layer, second layer as hidden layer and third layer as output layer

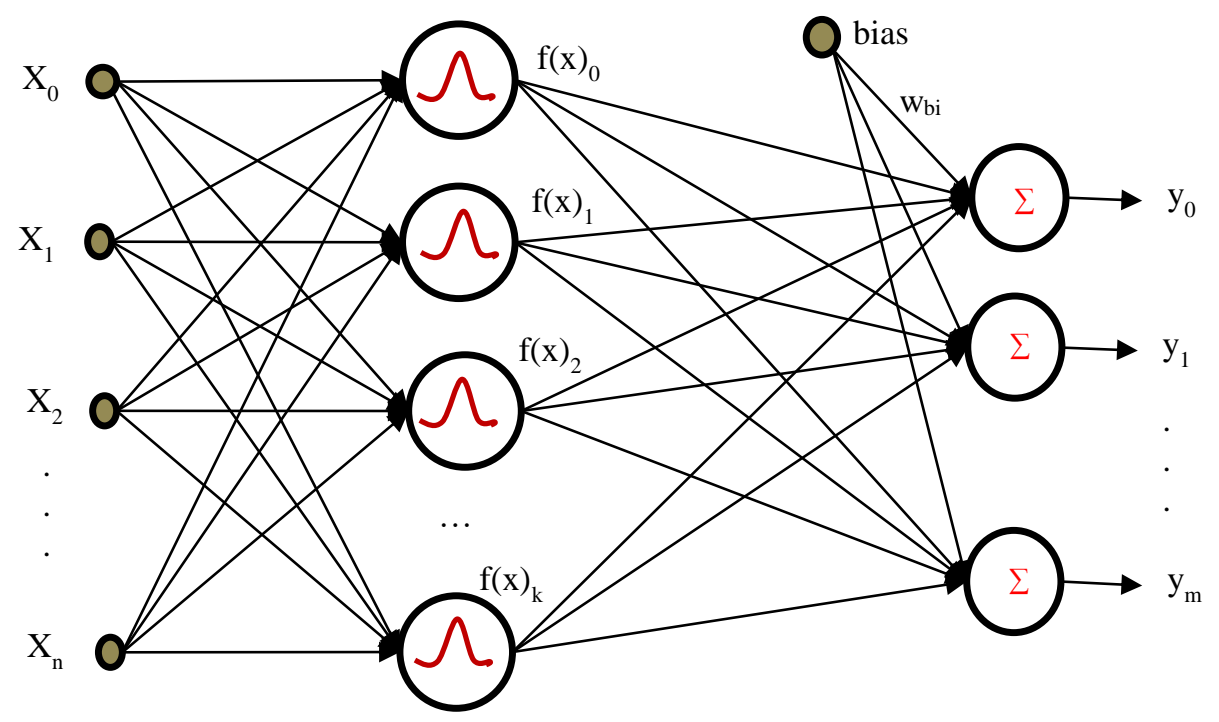

Fig. 2. The RBF Neural Network Structure

In the input layer-hidden layer and hidden layer-output layer, all nodes are interconnected. Only connections between the hidden layer and the output layer have weight (w) values. Since each hidden layer node represents a class (centrality), the number of nodes in the hidden layer must be greater than the number of nodes in the input layer. Different radial functions (Gaussian radial function, Thin plate spline, Quadratic, Inverse quadratic) are used as hidden layer transfer function (Behera, 2018). The most popular radial function is Gaussian radial function defined by Eq. (1).

$f(x)_{i}=\exp \left(-\frac{\left\|\mathrm{x}_{\mathrm{i}}-\mathrm{C}_{\mathrm{i}}\right\|^{2}}{2 \sigma_{i}^{2}}\right)$

where $\sigma_{i}$ is the $i$ th centrality distance, $c_{i}$ is $i$ th centrality. The output of the RBF neural network can be formed by a linear function of the hidden layer responses, which is shown as follows:

$y_{i}=b+\sum_{i=0}^{m}\left(w_{i} * f(x)_{i}\right)$

The network learning process is the process of determining weight values to minimize the amount of output error. Therefore, any optimization method can be used for this process. Different algorithms such as PseudoInverse Technique, Hybrid Learning, Levenberg-Marquardt and Gradient Descent Learning are used for the RBF network supervised learning method in the literature (Godoy et al., 2014; Behera, 2018). Gradient Descent Learning algorithm is preferred in this study. The output function of the network 
is reflected back to the weight and centrality values and it is computed as follows:

$$
\mathrm{C}_{(\mathrm{n}+1)}=\mathrm{C}_{\mathrm{n}}+\eta\left(\frac{\partial E}{\partial C}\right)
$$

where $\eta$ is the learning rate. Additional studies of the RBF neural network can be found in (Parsaie and Haghiabi, 2015; Montazer and Giveki, 2015; Zhao et al., 2015; Tatar et al., 2015), and the references cited therein.

$$
(M A E)=\frac{1}{n} \sum_{i=1}^{n}\left|d_{i}-y_{i}\right|
$$

where $d_{i}$ indicates desired output value, $y_{i}$ denotes calculated output value for input data $\left(x_{i}\right)$. These values are updated and learning is performed. The amount of the output error determines the performance of the network. Accordingly, in order to obtain the minimum error value, the training process is performed by changing the weight and centrality values taking into account the derivation of the error function and the learning coefficient data according to the gradient descent learning method (Eq. (4) and Eq. (5)).

$\mathrm{w}_{(\mathrm{n}+1)}=\mathrm{w}_{\mathrm{n}}+\eta\left(\frac{\partial E}{\partial w}\right)$

\section{Result and Discussion}

In this study, the RBF neural network assisted with gradient descent learning algorithm was utilized to predict wood composite materials. Mechanical and physical properties such as full dry board density $\left(\mathrm{gr} / \mathrm{cm}^{3}\right)$, bending strength $\left(\mathrm{N} / \mathrm{mm}^{2}\right)$, bending elastic modulus $\left(\mathrm{N} / \mathrm{mm}^{2}\right)$ and tensile strength $\left(\mathrm{N} / \mathrm{mm}^{2}\right)$ of four different wood composite materials (particleboard, fiberboard, oriented strand board and plywood) were taken into account. The details of the data used in the study are listed in Table 1.

\begin{tabular}{|c|c|c|c|c|c|}
\hline Material & $\begin{array}{l}\text { Data } \\
\text { Count }\end{array}$ & $\begin{array}{l}\text { Mechanical and Physical } \\
\text { Properties }\end{array}$ & $\begin{array}{l}\text { Standard } \\
\text { Deviation }\end{array}$ & $\begin{array}{l}\text { Maximum } \\
\text { Value }\end{array}$ & $\begin{array}{l}\text { Minimum } \\
\text { Value }\end{array}$ \\
\hline \multirow{4}{*}{ Fiberboard } & \multirow{4}{*}{31} & Board Density & 0,0035 & 0,85 & 0,67 \\
\hline & & Bending Strength & 5,82 & 47,04 & 23,27 \\
\hline & & Bending Elastic Modulus & 463,79 & 4602,35 & 2874,22 \\
\hline & & Tensile Strength & 113,41 & 632 & 0,25 \\
\hline \multirow{4}{*}{ Particleboard } & \multirow{4}{*}{29} & Board Density & 1,55 & 6,698 & 0,5 \\
\hline & & Bending Strength & 1,43 & 16,8 & 11,21 \\
\hline & & Bending Elastic Modulus & 165,88 & 2200 & 1595 \\
\hline & & Tensile Strength & 0,058 & 0,55 & 0,34 \\
\hline \multirow{4}{*}{$\begin{array}{l}\text { Oriented } \\
\text { Strand Board }\end{array}$} & \multirow{4}{*}{19} & Board Density & 129,08 & 650 & 65 \\
\hline & & Bending Strength & 2,29 & 24,12 & 16 \\
\hline & & Bending Elastic Modulus & 674,65 & 6301 & 3100 \\
\hline & & Tensile Strength & 0,066 & 0,45 & 0,22 \\
\hline \multirow{4}{*}{ Plywood } & \multirow{4}{*}{20} & Board Density & 0,0259 & 0,77 & 0,65 \\
\hline & & Bending Strength & 15,61 & 113,59 & 62 \\
\hline & & Bending Elastic Modulus & 1234,21 & 10000 & 5500 \\
\hline & & Tensile Strength & 0,77 & 3,4 & 0,71 \\
\hline
\end{tabular}

Table 1. Mechanical and physical properties of materials and numerical data. 
Table 2. RBF network structure

\begin{tabular}{llll}
\hline $\begin{array}{l}\text { Input } \\
\text { Layer } \\
\text { Nodes }\end{array}$ & $\begin{array}{l}\text { Maximum } \\
\text { Hidden } \\
\text { Layer } \\
\text { Nodes }\end{array}$ & $\begin{array}{l}\text { Output } \\
\text { Layer } \\
\text { Nodes }\end{array}$ & $\begin{array}{l}\text { Cost } \\
\text { Function }\end{array}$ \\
\hline 4 & 75 & 1 & MAE \\
\hline
\end{tabular}

The RBF network used in the study was trained by 90 iterations with 99 data sets and the performance graph is shown in Fig. 3

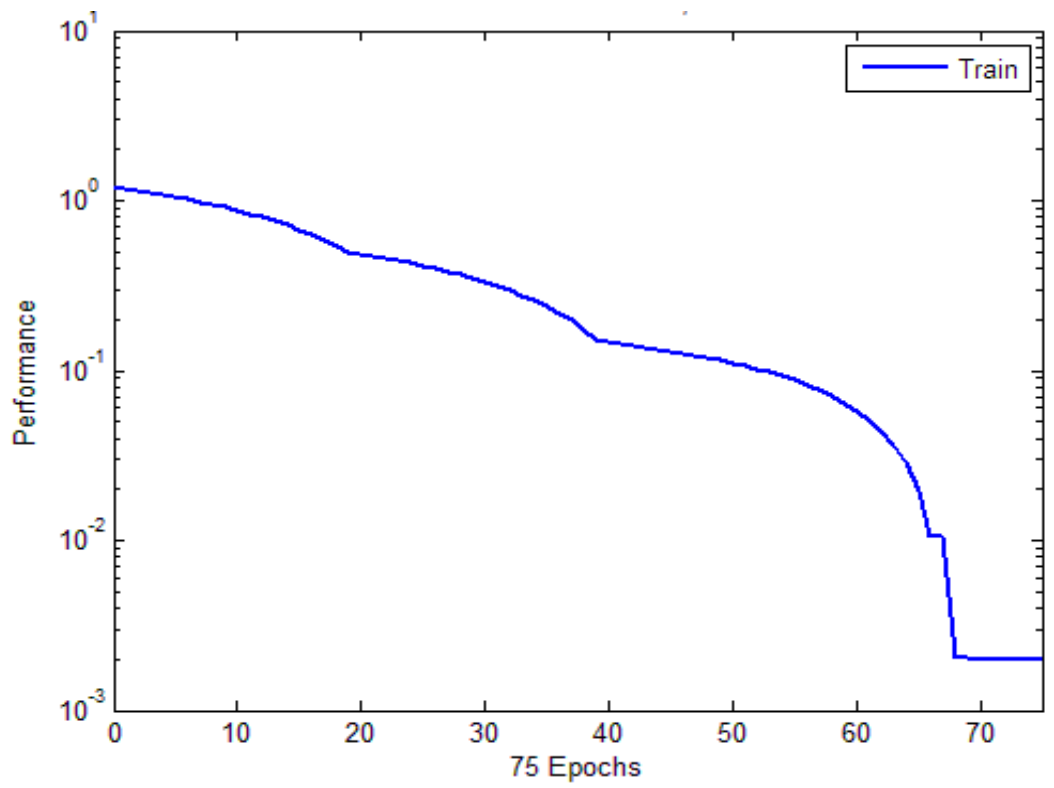

Fig. 3. Supervised Training Performance Graphic

The iterations after 90 iterations have been cut here because they have not been shown to have much effect on performance. During the iteration, the number of nodes in the hidden layer increased one by one starting from 4 and the optimal solution was obtained with 75 nodes. The RBF neural network learning parameters and performance value are shown in Tables 3 .
$70 \%$ of the data was used for training and remaining $30 \%$ was used for testing. The test data consisted of randomly selected data from the dataset that the network did not see previously. The network correctly predicted 28 of the 30 test data and viewed the two oriented strand boards as particleboard (Table 4). The test performance of the network was found at the accuracy levels of $93.3 \%$. With 10fold cross-validation, the network performance was found at the accuracy levels of $95.9 \%$.

Table 3. The RBF network learning parameters and performance value

\begin{tabular}{cccc}
\hline Spread Constant & MAE Goal & Maximum Number of Hidden Neuron & Performance \\
\hline 1 & 0.001 & 75 & 0.033 \\
\hline
\end{tabular}


Table 4. Test data confusion matrix

\begin{tabular}{lcccc}
\hline \multicolumn{1}{c}{ Material } & Fiberboard & Particleboard & Plywood & Oriented Strand Board \\
\hline Fiberboard & 11 & & & \\
\hline Particleboard & & 6 & 2 \\
\hline Plywood & & & 6 \\
\hline $\begin{array}{l}\text { Oriented Strand } \\
\text { Board }\end{array}$ & & 5 & \\
\hline
\end{tabular}

\section{Conclusions}

In this paper, the RBF neural network was employed for the prediction of wood composite materials such as particleboard, fiberboard, oriented strand board and plywood. Four physical and mechanical properties such as the board density, bending strength, bending elastic modulus and tensile strength were used in the prediction of the wood composite materials. The test performance of the network was found at the accuracy levels of $93.3 \%$. With 10-fold crossvalidation, the network performance was found at the accuracy levels of $95.9 \%$. The results show that the RBF neural network can be used to predict wood composite materials based on their mechanical and physical properties. Moreover, this study will assist wood composite users in the selection of wood composite materials that will provide the mechanical and physical properties determined in advance for any construction.

\section{References}

Avramidis, S., Iliadis, L. 2005. Predicting Wood Thermal Conductivity using Artificial Neural Networks, Wood and Fiber Science, 37(4), 682-690.

Behera L. 2018. Lecture Notes. http://home.iitk.ac.in/ lbehera/Files/Le cture5_RBFN.pdf

(Accessed 20.04.2018).

Cai, Z., Ross, R. J. 2010. Mechanical properties of wood-based composites materials, In: Wood Handbook, Wood as an Engineering Material, U.S. Department of Agriculture, Forest Service, Forest Products Laboratory, General Technical Report FPL-GTR190, Madison, 12-1-12-12.

Cook, D. F., Chiu, C. C. 1997. Predicting the Internal Bond Strength of Particleboard, Utilizing a Radial Basis Function Neural Network, Engineering Applications of Artificial Intelligence, 10(2), 171-177.

Esteban, L. G., de Palacios, P., Fernández, F. G. 2010. Use of Artificial Neural Networks as a Predictive Method to Determine Moisture Resistance of Particle and Fiber Boards Under Cyclic Testing Conditions (UNE-EN 321), Wood and Fiber Science, 42(3), 335345.

Fernandez, F. G., Esteban, L. G., de Palacios, P., Navarro, N., Conde, M. 2008. Prediction of Standard Particleboard Mechanical Properties Utilizing an Artificial Neural Network and Subsequent Comparison with a Multivariate Regression Model, Investigación Agraria: Sistemas y Recursos Forestales, 17(2), 178-187.

Fernandez, F. G., de Palacios, P., Esteban, L. G., Iruela, A. G., Rodrigo, B. G., Menasalvas, E. 2012. Prediction of MOR and MOE of Structural Plywood Board using an Artificial Neural Network and Comparison with a 
Multivariate Regression Model, Composites Part B, 43, 3528-3533.

Ilkucar, M., Kaya, A. I., Cifci, A. 2018. Mekanik Özelliklere Göre Ağaç Türlerinin Yapay Sinir Ağları ile Tahmini, Gümüşhane Üniversitesi Fen Bilimleri Enstitüsü Dergisi, 8(1), 75-83.

Marcano-Cedeño, A., QuintanillaDomínguez, J., Andina, D. 2009. Wood Defects Classification using Artificial Metaplasticity Neural Network, $35^{\text {th }}$ Annual Conference of the IEEE Industrial Electronics Society, Porto, Portugal, 3422-3427.

Melo, R. R., Miguel, E. P. 2016. Use of Artificial Neural Networks in Predicting Particleboard Quality Parameters, Revista Árvore, 40(5), 949-958.

Miguel, E. P., de Melo, R. R., Junior, L. S., Del Menezzi, C. H. S. 2018. Using Artificial Neural Networks in Estimating Wood Resistance, Maderas. Ciencia y Tecnología, 20 (unassigned).

Montazer, G. A., Giveki, D. 2015. An Improved Radial Basis Function Neural Network for Object Image Retrieval, Neurocomputing, 168, 221-233.

Ozşahin Ş. 2012. The Use of Artificial Neural Network for Modeling the Moisture Absorption and Thickness Swelling Properties of Oriented Standard Board, BioResources, 7(1), 1053-1067.

Parsaie, A, Haghiabi, A. H. 2015. Predicting the Longitudinal Dispersion Coefficient by Radial Basis Function Neural Network, Modeling Earth Systems and Environment, 1(4), 1-8.

P'erez-Godoy, M. D., Rivera, A. J., Carmona, C. J., del Jesus M. J. 2014. Training Algorithms for Radial Basis Function Networks to Tackle Learning Processes with Imbalanced Data-Sets, Applied Soft Computing, 25, 26-39.

Qayyum, R., Kamal, K., Zafar, T., Mathavan, S. 2016. Wood Defects Classification using GLCM based Features and PSO Trained Neural Network, 22 ${ }^{\text {nd }}$ International Conference on Automation and Computing (ICAC), Colchester, UK, 273-277.

Shahnorbanun, S., Siti Nurul Huda, S. A., Haslina, A., Nazlia, O., Rosilah, H. 2010. A Computational Biological Network for Wood Defect Classification, World Congress on Engineering and Computer Science (WCECS), San Francisco, USA, 1-5.

Tatar, A., Naseri, S., Sirach, N., Lee, M., Bahadori, A. 2015. Prediction of Reservoir Brine Properties using Radial Basis Function (RBF) Neural Network, Petroleum, 1(4), 349-357.

Tchircoff, A. 2018. The Mostly Complete Chart of Neural Networks, Explained. https://towardsdatascience.com/themostly-complete-chart-of-neuralnetworks-explained-3fb6f2367464 (Accessed 24.04.2018).

Tiryaki, S., Ozşahin, S., Yıldırım, I. 2014. Comparison of Artificial Neural Network and Multiple Linear Regression Models to Predict Optimum Bonding Strength of Heat Treated Woods, International Journal of Adhesion \& Adhesives, 55, 29-36.

Xu, X., Yu, Z. T., Hu, Y. C., Fan, L. W., Tian, T., Cen, K. F. 2007. Nonlinear Fitting Calculation of Wood Thermal Conductivity using Neural Networks, Journal of Zhejiang University, 41(7), 1201-1204.

Zhang, J., Cao, J., Zhang, D. 2006. ANNbased Data Fusion for Lumber Moisture Content Sensors, Transactions of the 
Institute of Measurement and Control, 28(1), 69-79.

Zhao, N., Wen, X., Yang, J., Li, S., Wang, Z. 2015. Modeling and Prediction of Viscosity of Water-Based Nanofluids by Radial Basis Function Neural Networks, Powder Technology, 281, 173-183. 